\title{
CHANGES IN THE REGULATORY BASE OF THE BUDGETARY PROCESS IN MAY 2013
}

\author{
M.Goldin
}

In May 2013, Resolution of the Government of the Russian Federation introducing from the beginning of 2014 the procedure for carrying out of open technological and pricing audit of large investment projects with state participation was published.

By Resolution No.382 of April 30, 2013 of the Government of the Russian Federation on Carrying Out of Open Technological and Pricing Audit of Large Investment Projects with State Participation and Amendment of Some Statutory Acts of the Government of the Russian Federation, the Statute was approved as regards regulation of procedures for open technological and pricing audit of large investment projects with participation of the state in respect of capital development projects whose financing of building, modernization or technological overhaul is planned to be carried out completely or partially at the expense of federal budget funds with utilization of the mechanism of federal target investment program, as well as budget allocations of the Investment Fund of the Russian Federation. Also, by the above Resolution of the Government of the Russian Federation a number of amendments to statutory acts of the Russian Federation was approved in connection with introduction of new procedures.

Instructions to the Government of the Russian Federation to ensure starting from 2013 organization of mandatory open technological and pricing audit of all the large investment projects with state participation were approved by Order No.596 of May 7, 2012 of the president of the Russian Federation on the Long-Term State Economic Policy. In addition to the above, late in March 2012 V. Putin, Chairman of the Government of the Russian Federation approved instructions to the Ministry of Economic Development of the Russian Federation to submit by July 1, 2012 the proposals on organization of mandatory open technological and pricing audit of all the large investment projects with state participation from 2012.

At the same time, in the above documents no explanation of "the open technological and pricing audit" was provided nor were the methods of such an audit specified; it is not explained either what "the state participation in investment projects and forms of state participation in investment projects" in respect of which open technological and pricing audit is expected to be introduced mean. In particular, it was not clear if the "openness" of such an audit suggests carrying out of the debates (expert review) of planned investment projects with the public.

An open technological audit of an investment project is determined by the Statute as an expert evaluation of justification of compliance of the selection of design technological and construction solutions as regards creation within the frameworks of the investment project of a capital development project to the best domestic and international building technologies, technological and structural design, modern building materials and equipment used in development with taking into account the requirements of modern production technologies required for functioning of the capital development project, as well as maintenance costs on realization of the investment project during the life cycle for the purpose of raising efficiency of utilization of budget funds, reduction of the costs and the period of development and increasing of competitiveness of production.

The pricing audit of the investment project is determined as an expert evaluation of the cost of the capital development project with taking into account of the outputs of the open technological audit of the investment project.

The Statute sets the lower limit of the project cost of capital development projects; with project costs exceeding that limit the open technological and pricing audit of investment projects is mandatory. It is to be noted that in 2014 that limit will amount to Rb 8bn and more, while from 2015, to $\mathrm{Rb} 1.5 \mathrm{bn}$ and more.

An open technological and pricing audit will be carried out in implementation of the following types of investment projects: 
a) capital investment projects which were included in federal target programs and those which were not;

b) investment programs which are planned to be funded at the expense of budget allocations from the Investment Fund of the Russian Federation.

Open technological and pricing audit is carried out in two stages:

The $1^{\text {st }}$ stage - at the stage of development of a decision on allocation of federal budget funds for implementation of the investment project or taking of a decision on consolidation of investment projects;

The $2^{\text {nd }}$ stage - at the stage of approval of the project documentation as regards the volume of capital development created in the course of implementation of the project.

The right to carry out an open technological and pricing audit of investment projects will be granted to independent expert entities and individuals included in the list of expert entities and individuals (experts) which can be engaged in carrying out of the open technological and pricing audit of investment projects; the above list is to be approved by the document of the Federal Agency for Building and Public Utilities. By the same document, the procedure for formation of the above list will be approved.

Though the above list and procedure for formation thereof are still to be approved, a number of criteria for selection of expert entities and experts has been secured by the Statute.

In selection of an expert entity, one should be guided by the following criteria:

a) work experience of at least 7 years including in respect of at least 5 investment projects worth $\mathrm{Rb}$ 1.5bn and more in the sphere of technological and pricing audit of investment projects as regards design and building of capital development projects by lines of implementation of investment projects;

b) mandatory participation of at least 5 experts with specialized education and at least 5 -year work experience in that sphere in fulfillment of jobs (rendering of services) as regards technological and pricing audit of investment projects;

c) knowledge by experts of the expert organization of the legislation of the Russian Federation in the sphere of urban planning activities and legislation on technical regulation (including requirements to safe operation of projects) as regards fulfillment of engineering survey for the purpose of design, building and operation of capital development projects, as well as design, building and operation of capital development projects by lines of implementation of investment project;

d) knowledge by experts of the expert organization of the Russian building market, including building materials, structures and construction engineering, cargo transportation market and labor market, including knowledge of their pricing parameters.

In selection of experts, one should be guided by the following criteria:

a) vocational training of the respective profile;

b) record of service of at least 5 years in the sphere of preparation of design documentation and (or) fulfillment of engineering surveys by lines of implementation of investment projects worth $\mathrm{Rb}$ $1.5 \mathrm{bn}$ or the record of service of at least 3 years at relevant offices at public authorities or entities carrying out due diligence of the design documentation and (or) the one of the outputs of engineering surveys;

c) lack of unquashed or outstanding conviction for commitment of intentional crime;

d) knowledge which meets relevant requirements set to experts of expert organizations which bid for participation in open technological and pricing audit of investment projects.

For carrying out of the first stage of the open technological and pricing audit and the second stage of the open technological audit of investment projects under which the design documentation is to be prepared in respect of capital development projects, a fee will be charged in favor of expert organizations and individuals in the amount not exceeding $0.2 \%$ and $0.38 \%$, respectively of the total cost of preparation of the design documentation and engineering survey materials.

For carrying out of an open technological and pricing audit of investment projects under which the design documentation in respect of capital development projects was developed, expert organizations and individuals charge a fee in the amount not exceeding $0.58 \%$ of the total cost of preparation of project documentation and engineering survey materials. 